\title{
S33 Fig.
}

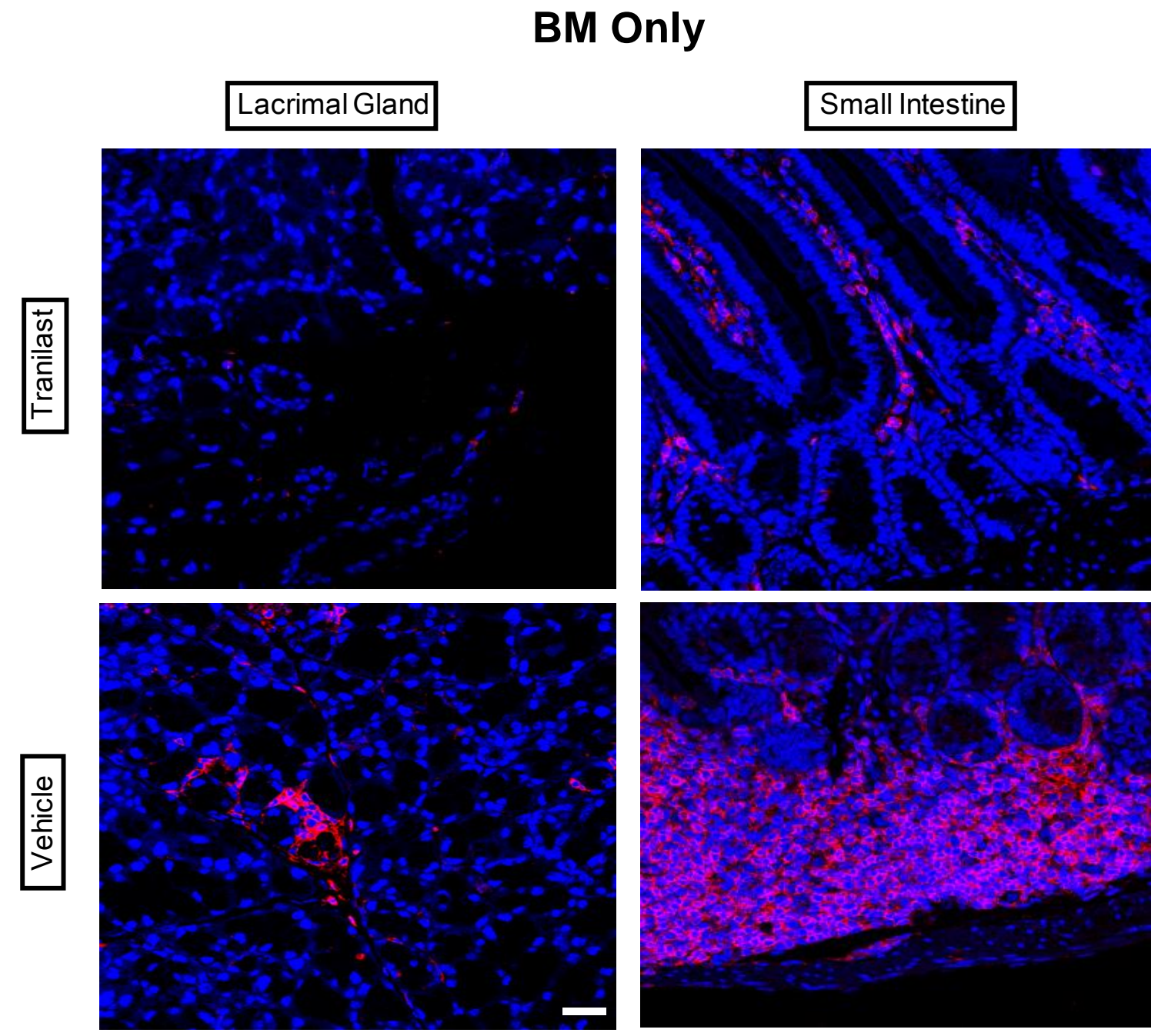

